\title{
Possible Intracellular Regulators of Female Sexual Maturation
}

\author{
A. KOLESAROVA ${ }^{1}$, A. V. SIROTKIN ${ }^{2}$, M. MELLEN ${ }^{3}$, S. ROYCHOUDHURY ${ }^{4}$ \\ ${ }^{1}$ Department of Animal Physiology, Faculty of Biotechnology and Food Sciences, Slovak \\ University of Agriculture, Nitra, Slovak Republic, ${ }^{2}$ Institute for Farm Animal Genetics and \\ Reproduction, National Agricultural and Food Centre, Nitra, Lužianky, Slovak Republic, ${ }^{3}$ Poultry \\ Slovakia, Ltd., Zvolen-Lieskovec, Slovak Republic, ${ }^{4}$ Department of Life Science and \\ Bioinformatics, Assam University, Silchar, India
}

Received June 5, 2014

Accepted October 15, 2014

On-line December 22, 2014

\begin{abstract}
Summary
Protein kinases, transcription factors and other apoptosis- and proliferation-related proteins can regulate reproduction, but their involvement in sexual maturation remains to be elucidated. The general aim of the in vivo and in vitro experiments with porcine ovarian granulosa cells was to identify possible intracellular regulators of female sexual maturation. For this purpose, proliferation (expression of proliferating cell nuclear antigen PCNA, mitogen-activated protein kinases - ERK 1,2 related MAPK and cyclin B1), apoptosis (expression of the apoptotic protein Bax and apoptosis regulator $\mathrm{Bcl}-2$ protein), expression of some protein kinases (cAMP dependent protein kinase - PKA, cGMPdependent protein kinase - PKG, tyrosine kinase - TK) and CAMP responsive element binding protein 1 (CREB-1) was examined in granulosa cells isolated from ovaries of immature and mature gilts. Expression of PCNA, ERK1,2 related MAPK, cyclin B1, Bcl-2, Bax, PKA, CREB-1, TK and PKG in porcine granulosa cells were detected by immunocytochemistry. Sexual maturation was associated with significant increase in the expression of $\mathrm{Bcl}-2$, Bax, PKA, CREB-1 and TK and with decrease in the expression of ERK1,2 related MAPK, cyclin B1 and PKG in granulosa cells. No significant difference in PCNA expression was noted. The present data obtained from in vitro study indicate that sexual maturation in females is influenced by puberty-related changes in porcine ovarian signaling substances: increase in Bcl-2, Bax, PKA, CREB-1, TK and decrease in ERK1,2 related MAPK, cyclin B1 and PKG. It suggests that these signaling molecules could be potential regulators of porcine sexual maturation.
\end{abstract}

\section{Key words}

Ovary • Kinases • Proliferation • Apoptosis • Transcription factor

\section{Corresponding author}

A. Kolesarova, Department of Animal Physiology, Faculty of Biotechnology and Food Sciences, Slovak University of Agriculture, 94976 Nitra, Slovak Republic. E-mail: Adriana.Kolesarova@uniag.sk

\section{Introduction}

Sexual maturation is associated with ovarian follicular growth and differentiation (Onagbesan et al. 2009, Palma et al. 2012). These processes are governed by hormones, growth factors (Kolesarova et al. 2009a,b, 2010a,b, Roychoudhury et al. 2009, 2014), which through protein kinases and transcription factors, affect ovarian cell proliferation, apoptosis and secretion activity (Onagbesan et al. 2009, Sirotkin 2013). There is indirect evidence for involvement of several candidate signaling substances in control of sexual maturation and/or related ovarian follicle development.

Action of hormones and growth factors on ovarian folliculogenesis and functions is mediated via protein kinases and related proliferation- and apoptosisrelated peptides (Sirotkin et al. 2000, 2008). The involvement of cAMP/protein kinase A (PKA)dependent intracellular mechanisms (Makarevich et al. 2000, Sirotkin and Grossmann 2003, 2006) in the regulation of proliferation- and apoptosis-related 
substances (Sirotkin and Grossmann 2003, 2006) has already been reported. Furthermore, cAMP/PKA can regulate the secretion activity of mammalian ovarian cells as noted in cases of porcine (Sirotkin et al. 2004), chicken (Sirotkin and Grossmann 2006) and human (Sirotkin et al. 2008) ovarian cells and also mediate the action of hormones and growth factors on ovarian functions (Makarevich et al. 2004a,b). Apoptosisrelated substances are crucial in follicular selection, atresia and corpus luteum regression (Parborell et al. 2001, 2008, Greenfeld et al. 2007, Maeda et al. 2007). Mitochondrial apoptotic protein Bax is considered as the key pro-apoptotic substance (Elmore 2007), whilst apoptosis regulator Bcl-2 protein, which binds and inactivates Bax, has an opposite, anti-apoptotic action (Greenfeld et al. 2007, Lomonosova and Chinnadurai 2008). The mitogen-activated protein kinases (MAPK) signaling cascade including intracellular regulated kinases (ERK) also act as promoters of cell cycle progression as well as mediators of mitogenic action of hormones and growth factors (Lapthorn et al. 1994, Cameron et al. 1996, Sirotkin and Grossmann 2003), stimulators of ovarian cell proliferation, differentiation and secretion activity (Sirotkin and Grossmann 2003) and suppressors of apoptosis (Xia et al. 1995, Dent et al. 1998, Kyriakis 1999, Gunter et al. 2013). Tyrosine kinase (TK) localized in growth factor receptors and cytoplasm plays an important role in promoting cell proliferation, differentiation and mediation effects of some hormones and growth factors in signal transduction (Okamura et al. 2001, Sirotkin and Grossmann 2003, Arora and Scholar 2005). TK may be involved in activation of ovarian porcine follicle growth and maturation (Okamura et al. 2001) and in control of chicken ovarian cell proliferation and hormone release (Sirotkin and Grossmann 2003).

The involvement of cGMP dependent protein kinase (PKG) along with cGMP in control of the production of steroid, nonapeptide hormone, growth factor, cAMP and cAMP-dependent PKA, as well as the induction of apoptosis in porcine ovarian cells has been reported, too (Sirotkin et al. 2000). Protein kinases (PKA, MAPK) can also target cAMP responsive element binding protein 1 (CREB-1). It is required for mediating stimulatory influence of FSH on granulosa and luteal cells differentiation and steroidogenesis during the follicular recruitment estrous cycle and pregnancy of mouse (Mendelson and Kamat 2007). There exist indirect evidences for involvement of CREB in control of sexual maturation (Sirotkin et al. 2004, He et al. 2006). Cell cycle peptides especially proliferating cell nuclear antigen PCNA (Naryzhny and Lee 2001) and cyclin B1 (Wyllie et al. 1998) are also involved in ovarian cell proliferation, growth and development (Tomanek and Chronowska 2006). Proliferation-related peptide PCNA is a known promoter of the cell cycle transition through G1 and G2 phases. Furthermore, it activates the cyclin/cyclin dependent kinase complex (McHugh and Sarkar 2006, Moldovan et al. 2007), which promotes the $\mathrm{G}_{2}-\mathrm{M}$ transition of the cell cycle (Hassan et al. 2001). Expression of PCNA and cyclin B1 in ovarian cells has been reported from different mammalian species (Hutt et al. 2006, Sirotkin et al. 2008).

The general aim of the in vivo and in vitro experiments with porcine ovarian granulosa cells was to identify possible intracellular regulators of female sexual maturation. For this purpose, expression of these signaling molecules were evaluated in granulosa cells collected from sexually mature and immature gilts of the same age.

\section{Materials and Methods}

\section{Animals}

Healthy gilts of Slovakian White breed (100-120 days of age) were reared under standard conditions at the Experimental Station of the Slovak University of Agriculture in Nitra, Slovakia. Conditions of their care and handling corresponded to the instructions of the European Commission (EC) no. 178/2002 and related EC documents and as approved by local ethics committee. Animals $(n=35)$ were assigned at slaughter into two groups: sexually immature $(n=18)$ and animals of the same age having reached sexual maturity $(n=17)$ according to visual characteristics of ovaries (presence of follicles larger than $5 \mathrm{~mm}$ ).

\section{Preparation, culture and processing of granulosa cells}

Ovaries were transported to the laboratory at $4{ }^{\circ} \mathrm{C}$ and washed in sterile physiological solution. Ovaries from immature and mature gilts were processed separately. Follicular fluid was aspirated from 3-5 mm follicles, granulosa cells were isolated by centrifugation for $10 \mathrm{~min}$ at $200 \mathrm{xg}$ followed by washing in sterile DMEM/F12 1:1 medium (BioWhittaker ${ }^{\mathrm{TM}}$, Verviers, Belgium) and resuspended in the same medium supplemented with $10 \%$ fetal calf serum 
(BioWhittaker ${ }^{\mathrm{TM}}$ ) and $1 \%$ antibotic-antimycotic solution (Sigma, St. Louis, MO, USA) at a final concentration of $10^{6}$ cells $/ \mathrm{ml}$ of medium. Portions of the cell suspension were dispensed to Lab-Tek 16-welled chamber slides (Nunc Inc., International, Naperville, USA, $100 \mu \mathrm{l} /$ well; for immunocytochemistry). Chamber slides were incubated at $37.5^{\circ} \mathrm{C}$ and $5 \% \mathrm{CO}_{2}$ in humidified air until a $75 \%$ confluent monolayer was formed (5-7 days), at which point the medium was replaced with fresh medium. Further culture was performed in $300 \mu \mathrm{l}$ medium in 16-welled chamber slide cells. After 2 days of culture the media from wells were removed, wells from chamber slides were washed in ice-cold PBS (pH 7.5). Cells were fixed for $1 \mathrm{~h}$ at room temperature in $4 \%$ paraformaldehyde, dehydrated in alcohols (70, 80, $96 \%$; $10 \mathrm{~min}$ each) and stored in $96 \%$ alcohol at $-4{ }^{\circ} \mathrm{C}$ to await immunocytochemical analysis.

\section{Immunocytochemistry}

Immunocytochemistry was used to detect PKA,

PKG, TK, ERK1,2 related MAP kinase, CREB-1, PCNA, cyclin B1, Bax, Bcl-2 in granulosa cells plated on chamber slides (Osborn and Isenberg 1994). Primary mouse monoclonal antibodies to each petide PKA, PKG, TK, CREB-1, PCNA, cyclin B1, Bax, Bcl-2 (crossreacting with corresponding rat, human, porcine and chicken substances; all from Santa Cruz Biotechnology Inc., Santa Cruz, CA, USA) were used as directed by the manufacturer at a dilution of 1:100 and ERK1,2 at a dilution of 1:50. Visualization of the primary antibody binding sites was done with a secondary rabbit polyclonal antibody against mouse IGs, labelled with horseradish peroxidase (Sevac, Prague, Czech Republic; dilution 1:500) and diaminobenzidine (DAB) reagent (Roche Diagnostics Corporation, IN, USA, $10 \%$ ). The presence of each peptide was determined by light microscopy. To verify these data, in some selected cases primary antibodies were visualized by secondary rabbit or goat monoclonal antibodies against mouse IGs labeled with FITC (Sevac, Prague, Czech Republic) and fluorescent microscopy. Negative control was presented by stained cells omitting primary antibody. During microscopic inspection, the percentage of cells containing visible antigen was determined.

\section{Statistics}

Each experimental group was represented by four chamber slide wells with granulosa cells. The data presented concerning the effects of each substance are means of values obtained in three separate experiments performed on separate days using separate ovaries obtained from 10-12 animals. The proportion of cells containing each analyzed substance was calculated following immunocytochemical analysis by counting at least 1000 cells per chamber slide well. Firstly, the data obtained in each experiment were processed by ANOVA. Thereafter, significant differences between the immature groups and mature gilts were evaluated by paired t-test or chi-square $\left(\chi^{2}\right)$ test by using statistical software Sigma Plot 9.0 (Jandel, Corte Madera, USA). Differences from controls $(\mathrm{p}<0.05)$ were considered as significant.

\section{Results}

Percentage of ovarian granulosa cells containing PCNA did not differ between sexually mature $(22.4 \pm 4.1 \%)$ and immature gilts $(17.5 \pm 1.2 \%)$ (Fig. 1). On the contrary, the expression of ERK1,2 related MAPK and cyclin B1 was significantly $(p<0.05)$ lower in granulosa cells of sexually mature gilts (ERK1,2 $35.3 \pm 1.6 \%$, cyclin B1 $21.8 \pm 0.6 \%$ ) in comparison to their immature counterparts (ERK1,2 46.2 $\pm 1.8 \%$, cyclin B1 38.2 $\pm 1.6 \%$ ) (Fig. 1).

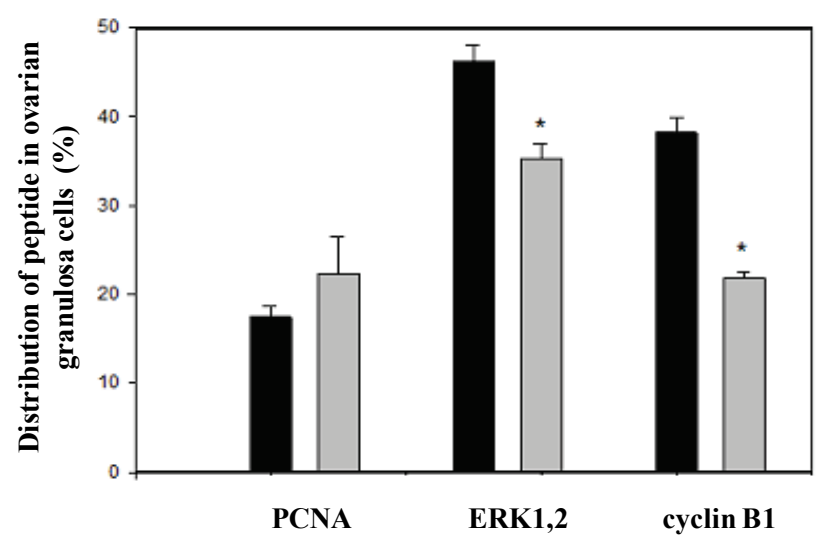

Fig. 1. Distribution of PCNA, ERK1,2 and cyclin $B 1$ in ovarian granulosa cells of sexually immature and mature gilts. * significant difference $(p<0.05)$ between corresponding groups of sexually immature $(n=18$, black column) and mature $(n=17$, grey column) gilts evaluated by t-test and chi-square $\left(\chi^{2}\right)$ test. Immunocytochemistry.

The expression of Bcl-2 and Bax by ovarian granulosa cells was significantly $(p<0.05)$ higher in sexually mature gilts in comparison to immature animals $(37.7 \pm 1.8 \%$ vs. $28.7 \pm 1.0 \%$ for Bcl- 2 and $48.7 \pm 2.6 \%$ vs. $31.9 \pm 2.3 \%$ for Bax, respectively) (Fig. 2).

Proportion of cells containing PKA was also 
significantly $(\mathrm{p}<0.05)$ higher in sexually mature gilts than in sexually immature animals (PKA $54.4 \pm 1.2 \%$ vs. $32.7 \pm 1.7 \%$ ) (Fig. 3). Similarly, expression of TK was significantly $(p<0.05)$ higher in sexually mature gilts in comparison to sexually immature ones (TK $41.4 \pm 1.1 \%$ vs. $32.4 \pm 3.3 \%$ ) (Fig. 3). Also, proportion of cells containing CREB-1 was significantly $(p<0.05)$ higher in sexually mature gilts than the immature animals (CREB $46.3 \pm 1.0 \%$ vs. CREB $38.6 \pm 0.7 \%$ ). However, the expression of PKG was significantly lower $(\mathrm{p}<0.05)$ in granulosa cells of sexually mature gilts than the immature animals (PKG $16.7 \pm 2.2 \%$ vs. PKG $61.3 \pm 2.1 \%$ ) (Fig. 3).

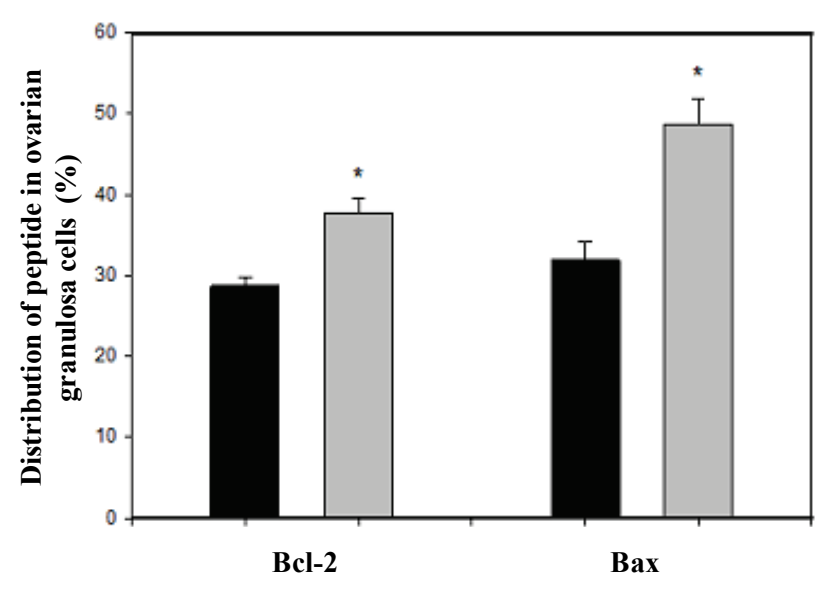

Fig. 2. Distribution of $\mathrm{BCl}-2$ and Bax in ovarian granulosa cells of sexually immature and mature gilts. * significant difference $(p<0.05)$ between corresponding groups of sexually immature $(n=18$, black column) and mature $(n=17$, grey column) gilts evaluated by t-test and chi-square $\left(\chi^{2}\right)$ test. Immunocytochemistry.

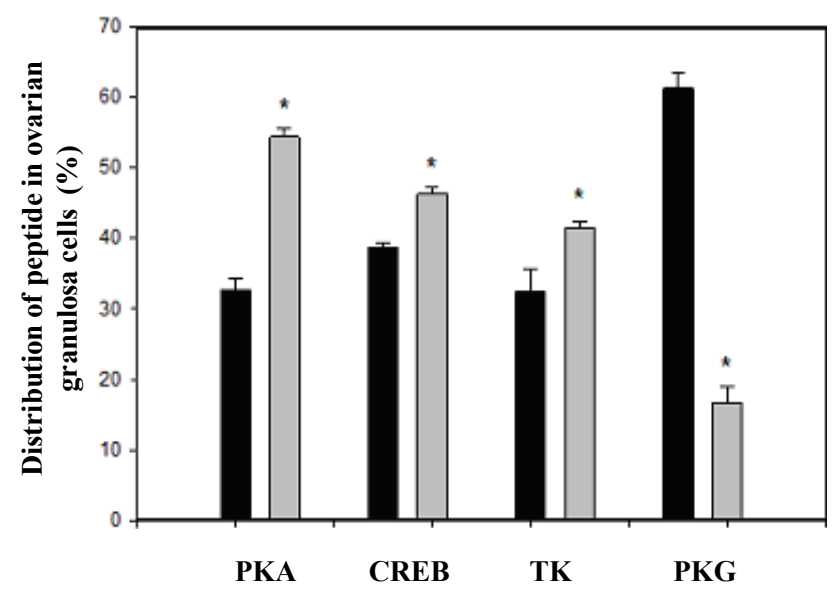

Fig. 3. Distribution of $P K A, C R E B, T K$ and $P K G$ in ovarian granulosa cells of sexually immature and mature gilts. * significant difference $(p<0.05)$ between corresponding groups of sexually immature $(n=18$, black column) and mature $(n=17$, grey column) gilts evaluated by t-test and chi-square $\left(\chi^{2}\right)$ test. Immunocytochemistry.

\section{Discussion and Conclusions}

Do peptides of cell proliferation (PCNA, ERK1,2 related $M A P K$ and cyclin B1) relate to sexual maturation?

Follicular growth and development in porcine ovary was associated with increased expression of PCNA in granulosa cell (Tomanek and Chronowska 2006). Peng et al. (1998) reported decreased expression of PCNA in granulosa cells during apoptosis. Our investigation did not reveal any differences in PCNA in granulosa cells between immature and mature gilts (Peng et al. 1998). In contrast to PCNA, the expression of cyclin B1 was associated with sexual maturation. Since cyclin B1 is a promoter and marker of G-phase of cell cycle (Wyllie et al. 1998), it might be suggested that sexual maturation is associated with suppression of cell cycle at this phase. Since ERK1,2 related MAPK is an important marker and promoter of cell cycle (Grossmann 2009), its role in stimulation of ovarian cell proliferation and related follicle growth during puberty may be suggested. During establishment of ovarian cyclicity the expression and probably the importance of ERK1,2 related MAPK declines. Besides cell proliferation ERK1,2 related MAPK can control apoptosis. In mammalian cells, the MAPK pathway can prevent (Allen et al. 1999, Anderson and Tolkovsky 1999, Nishio et al. 1999) or induce (Goillot et al. 1997, Bhat and Zhang 1999) apoptosis depending on the type of cell and the extracellular stimuli that initiate the pathway. Therefore, the changes in ERK1,2 related MAPK as observed in the present study could be due to its involvement in control of apoptosis during sexual maturation. Evidence also persists (Sirotkin and Grossmann 2003) that MAPK could be involved not only in control of apoptosis, but also in control of ovarian secretion activity and in mediating the effect of hormonal regulators of reproduction.

Results of the present study indicate that sexual maturation is associated with a reduction in the expression of ERK1,2 related MAPK and cyclin B1, but not of PCNA, which could result in reduction of ovarian cell proliferation, increase in their apoptosis and might even change their secretion activity and response to hormonal regulators during establishment of ovarian cycle.

Do anti-apoptotic peptide Bcl-2 and pro-apoptotic peptide Bax relate to sexual maturation?

In this study, sexual maturation in gilts was found to be associated with increased expression of both Bcl-2 and Bax by ovarian granulosa cells. Through their effect on 
apoptosis, these peptides could be involved in control of ovarian follicular growth, development and fertility. This is probably the first indication of involvement of ovarian Bax and Bcl-2 in control of porcine sexual maturation. The puberty-related increase in expression of both Bax and its antagonist Bcl-2 as observed in the present study suggest the involvement of these apoptosis-related peptides in regulation of porcine sexual maturation, although understanding their exact role in control of porcine reproduction requires further investigation.

Do PKA, CREB-1, TK and PKG relate to sexual maturation?

Stimulatory influence of PKA on ovarian secretory activity and in mediating the action of hormones and growth factors has been demonstrated previously (Makarevich et al. 2004a,b). The present study for the first time reports involvement of PKA in regulation of not only basal ovarian functions, but also of sexual maturation. It is possible that sexual maturityrelated increases in the expression of PKA as observed in this study are important for sexual maturity-associated increases in hormone and growth factor release and action.

It was previously mentioned that TK can be involved in activation of porcine ovarian follicle growth and maturation (Okamura et al. 2001) and in control of chicken ovarian cell proliferation and hormone release (Sirotkin and Grossmann 2003). Our observations present further involvement of TK in control of sexual maturityrelated changes in ovarian functions. Our observations provide the first indications of involvement of PKG in regulation of porcine sexual maturation. Involvement of cGMP/PKG system in control of release of porcine ovarian hormones has been reported previously (Sirotkin et al. 2000).

Also, our data provide the first indications of the role of CREB-1 in sexual maturation and related processes in gilts. Although involvement of CREB-1 in control of sexual maturation (Sirotkin et al. 2004, He et al. 2006) and in mediating the effect of growth factor on these processes (Sirotkin and Grossmann 2003) in nonporcine species has been documented, details of CREB-1 targets and action remain to be studied.

\section{Possible interrelationships between studied substances}

Effect of hormones and growth factors on the ovary can be mediated by protein kinases and protein kinases-dependent transcription factors. PKA can mediate the action of hormones and growth factors (Makarevich et al. 2004a,b). Furthermore, hormones and growth factors can affect ovarian function during and after puberty through MAPK-dependent intracellular mechanisms. At least, growth factors can activate MAPK in a variety of cell types (Lapthorn et al. 1994), and inhibitors of MAPK cascade can block the mitogenic action of the growth factors (Alessi et al. 1995). Furthermore, ability of PKA and TK to affect MAPK and MAPK-activated CREB-1 in non-ovarian cells has been reported (Gao et al. 2009, McAlees and Sanders 2009, Sun et al. 2009, Zu et al. 2009). Therefore, the functional interrelationships between these substances within the ovary in regulating porcine sexual maturation cannot be excluded. Fine interrelationships between analyzed processes occurring in porcine ovary during sexual maturation require further elucidation. Nevertheless, the present observations expand the existing knowledge concerning changes during sexual maturation in porcine ovarian hormones, growth factors and growth factors binding proteins. Furthermore, this is the first indication of involvement of some intracellular signaling substances in control of this process. Obtained results suggest that sexual maturation is associated with increase in expression of apoptosis-related substances (Bcl-2, Bax), PKA, TK, PKG, CREB-1, with decreases in the expression proliferation-related substances of ERK1,2 related MAPK and cyclin B1, but not PCNA. Analyzed data indicate puberty-related changes in porcine ovarian signaling substances: Bcl-2, Bax, PKA, CREB-1, TK, ERK1,2 related MAPK, cyclin B1 and PKG. Results obtained from both in vivo and in vitro studies indicate the involvement of some apoptosis- and proliferationrelated substances, protein kinases and transcription factor CREB-1 in porcine sexual maturation. The results of present study indicate that sexual maturation is associated with decrease in ovarian cells proliferation and increase in their secretory activity, apoptosis and expression of some protein kinases and transcription factor. Although the puberty-related changes do not provide direct evidence of the involvement and physiological role of these signaling molecules in control of sexual maturation, our study enables to identify several extra-and intracellular signaling substances, which could be potential candidates for induction of porcine puberty and sexual maturation.

\section{Conflict of Interest}

There is no conflict of interest. 


\section{Acknowledgements}

This work was supported by the Ministry of Education, Science, Research and Sports of the Slovak Republic (1/0022/13), Slovak Research and Development Agency of the Slovak Republic (APVV-0304-12) and the Department of Biotechnology, Government of India (BT/265/NE/TBP/2011).

\section{References}

ALESSI DR, CUENDA A, COHEN P, DUDLEY DT, SALTIEL AR: PD 098059 is a specific inhibitor of the activation of mitogen-activated protein kinase kinase in vitro and in vivo. J Biol Chem 270: 27489-27494, 1995.

ALLEN MP, ZENG C, SCHNEIDER K, XIONG X, MEINTZER MK, BELLOSTA P, BASILICO C, VARNUM B, HEIDENREICH KA, WEIRMAN ME: Growth arrest-specific gene 6 (Gas6)/adhesion related kinase (Ark) signaling promotes gonadotropin-releasing hormone neuronal survival via extracellular signal-regulated kinase (ERK) and Akt. Mol Endocrinol 13: 191-201, 1999.

ANDERSON CNG, TOLKOVSKY AM: A role for MAPK/ERK in sympathetic neuron survival: protection against a p53-dependent, JNKindependent induction of apoptosis by cytosine arabinoside. J Neurosci 19: 664-673, 1999.

ARORA A, SCHOLAR EM: Role of tyrosine kinase inhibitors in cancer therapy. J Pharmacol Exp Ther 315: 971-979, 2005.

BHAT NR, ZHANG P: Hydrogen peroxide activation of multiple mitogen-activated protein kinases in an oligodendrocyte cell line: role of extracellular signal-regulated kinase in hydrogen peroxide-induced cell death. J Neurochem 72: 112-119, 1999.

CAMERON MR, FOSTER JA, BUKOVSKY A, WIMALASENA J: Activation of mitogen-activated protein kinases by gonadotropins and cyclic adenosine 5'-monophosphates in porcine granulosa cells. Biol Reprod 55: 111-119, 1996.

DENT P, JARVIS WD, BIRRER MJ, FISHER PB, SCHMIDT-ULLRICH RK, GRANT S: The roles of signaling by the p42/p44 mitogen-activated protein (MAP) kinase pathway; a potential route to radio- and chemosensitization of tumor cells resulting in the induction of apoptosis and loss of clonogenicity. Leukemia 12: 1843-1850, 1998.

ELMORE S: Apoptosis: a review of programmed cell death. Toxicol Pathol 35: 495-516, 2007.

GAO J, SIDDOWAY B, HUANG Q, XIA H: Inactivation of CREB mediated gene transcription by HDAC8 bound protein phosphatase. Bioch Biophys Res Comm 379: 1-5, 2009.

GOILLOT E, RAINGEAUD J, RANGER A, TEPPER RI, DAVIS RJ, HARLOW E, SANCHEZ I: Mitogen-activated protein kinase-mediated Fas apoptotic signaling pathway. Proc Natl Acad Sci 94: 3302-3307, 1997.

GREENFELD CR, BABUS JK, FURTH PA, MARION S, HOYER PB, FLAWS JA: BAX is involved in regulating follicular growth, but is dispensable for follicle atresia in adult mouse ovaries. Reproduction 133: 107-116, 2007.

GROSSMANN AB: The molecular biology of pituitary tumors: a personal perspective. Pituitary 12: 265-270, 2009.

GUNTER JH, SARKAR PL, LUBIK AA, NELSON CC: New players for advanced prostate cancer and the rationalisation of insulin-sensitising medication. Int J Cell Biol 2013: Article ID 834684, 2013.

HASSAN KA, EL-NAGGAR AK, SORIA JC, LIU D, HONG WK, MAO L: Clinical significance of cyclin B1 protein expression in squamous cell carcinoma of the tongue. Clin Cancer Res 7: 2458-2462, 2001.

HE PJ, FUJIMOTO Y, YAMAUCHI N, HATTORI MA: Real-time monitoring of AMP response element binding protein signaling in porcine granulosa cells modulated by ovarian factors. Mol Cell Biochem 290: 177-184, 2006.

HUTT KJ, MCLAUGHLIN EA, HOLLAND MK: Primordial follicle activation and follicular development in the juvenile rabbit ovary. Cell Tissue Res 326: 809-822, 2006. 
KOLESAROVA A, CAPCAROVA M, SIROTKIN A, MASSANYI P: Insulin-like growth factor-I and progesterone release by ovarian granulosa cells of hens after experimental lead and molybdenum administrations in vitro. Int J Poultry Sci 8: 890-895, 2009a.

KOLESAROVA A, SLIVKOVA J, SIROTKIN A, MASSANYI P, CAPCAROVA M: The release of insulin-like growth factor-I by ovarian granulosa cells of pregnant sows after lead and mercury administration in vitro. Slovak J Anim Sci 42: 35-41, 2009b.

KOLESAROVA A, ROYCHOUDHURY S, SLIVKOVA J, SIROTKIN AV, CAPCAROVA M, MASSANYI P: In vitro study on the effect of lead and mercury on porcine ovarian granulosa cells. J Environ Sci Health A Tox Hazard Subst Environ Eng 45: 320-331, 2010a.

KOLESAROVA A, SIROTKIN AV, ROYCHOUDHURY S, CAPCAROVA M: Puberty related changes in hormonal levels, productive performance, carcass traits, and their interactions in Slovakian White gilts. Asian Australas $J$ Anim Sci 23: 182-187, 2010b.

KYRIAKIS JM: Making the connection: coupling of stress-activated ERK/MAPK (extracellular-signal-regulated kinase/mitogen-activated protein kinase) core signalling modules to extracellular stimuli and biological responses. Biochem Soc Symp 64: 29-48, 1999.

LAPTHORN AJ, HARRIS DC, LITTLEJOHN A, LUSTBADER JW, CANFIELD RE, MACHIN KJ, MORGAN FJ, ISAACS NW: Crystal structure of human chorionic gonadotropin. Nature 369: 455-461, 1994.

LOMONOSOVA E, CHINNADURAI G: BH3-only proteins in apoptosis and beyond: an overview. Oncogene 27: S2-S9, 2008.

MAEDA A, INOUE N, MATSUDA-MINEHATA, F, GOTO, Y, CHENG Y, MANABE N: The role of interleukin-6 in the regulation of granulosa cell apoptosis during follicular atresia in pig ovaries. $J$ Reprod Dev 53: 481-490, 2007.

MAKAREVICH AV, SIROTKIN AV, CHRENEK P, BULLA J, HETENYI L: The role of IGF-I, cAMP/protein kinase $A$ and MAP-kinase in the control of steroid secretion, cyclic nucleotide production, granulosa cell proliferation and preimplantation embryo development in rabbits. J Steroid Biochem Mol Biol 73: 123-133, 2000.

MAKAREVICH AV, SIROTKIN AV, FRANEK J, KWON HB, BULLA J: The role of oxytocin, protein kinase A, and ERK-related MAP-kinase in the control of porcine ovarian follicle functions. Exp Clin Endocrinol Diab 112: 108-114, 2004a.

MAKAREVICH AV, SIROTKIN AV, GENIESER HG: Action of protein kinases A regulators on secretory activity of porcine granulosa cells in vitro. Anim Reprod Sci 81: 125-136, $2004 \mathrm{~b}$.

MCALEES JW, SANDERS VM: Hematopoietic protein tyrosine phosphatase mediates beta2-adrenergic receptorinduced regulation of p38 mitogen-activated protein kinase in B lymphocytes. Mol Cell Biol 29: 675-686, 2009.

MCHUGH PJ, SARKAR S: DNA interstrand cross-link repair in the cell cycle: a critical role for polymerase zeta in G1 phase. Cell Cycle 5: 1044-1047, 2006.

MENDELSON CR, KAMAT A: Mechanisms in the regulation of aromatase in developing ovary and placenta. J Steroid Biochem Mol Biol 106: 62-70, 2007.

MOLDOVAN GL, PFANDER B, JENTSCH S: PCNA, the maestro of the replication fork. Cell 129: 665-679, 2007.

NARYZHNY SN, LEE H: Protein profiles of the Chinese hamster ovary cells in the resting and proliferating stages. Electrophoresis 22: 1764-1775, 2001.

NISHIO K, FUKUOKA K, FUKUMOTO H, SUNAMI T, IWAMOTO Y, SUZUKI T, USUDA J, SAIJO N: Mitogenactivated protein kinase antisense oligonucleotide inhibits the growth of human lung cancer cells. Int J Oncol 14: 461-469, 1999.

OKAMURA Y, MYOUMOTO A, MANABE N, TANAKA N, OKAMURA H, FUKUMOTO M: Protein tyrosine kinase expression in the porcine ovary. Mol Hum Reprod 7: 723-729, 2001.

ONAGBESAN O, BRUGGEMAN V, DECUYPERE E: Intra-ovarian growth factors regulating ovarian function in avian species: a review. Anim Reprod Sci 111: 121-140, 2009.

OSBORN M, ISENBERG S: Immunocytochemistry of frozen and of paraffin tissue sections. In: Cell Biology: A Laboratory Hanbook. Academic Press, New York/London, 1994, pp 361-367. 
PALMA GA, ARGANARAZ ME, BARRERA AD, RODLER D, MUTTO AA, SINOWATZ F: Biology and biotechnology of follicle development. ScientificWorldJournal 2012: Article ID 938138, 2012.

PARBORELL F, DAIN L, TESONE M: Gonadotropin-releasing hormone agonist affects rat ovarian follicle development by interfering with FSH and growth factors on the prevention of apoptosis. Mol Reprod Dev 60: 241-247, 2001.

PARBORELL F, ABRAMOVICH D, TESONE M: Intrabursal administration of the antiangiopoietin 1 antibody produces a delay in rat follicular development associated with an increase in ovarian apoptosis mediated by changes in the expression of BCL2 related genes. Biol Reprod 78: 506-513, 2008.

PENG X, MARUO T, MATSUO H, TAKEKIDA S, DEGUCHI J: Serum deprivation-induced apoptosis in cultured porcine granulosa cells is characterized by increased expression of p53 protein, Fas antigen and Fas ligand and by decreased expression of PCNA. Endocrinol J 45: 247-253, 1998.

ROYCHOUDHURY S, KOLESAROVA A, SLIVKOVA J, MASSANYI P, SIROTKIN AV, BULLA J: Release of IGF-I by porcine ovarian granulosa cells after in vitro copper administration. Acta Fytotech Zootech Special issue: 587-593, 2009.

ROYCHOUDHURY S, BULLA J, SIROTKIN AV, KOLESAROVA A: In vitro changes in porcine ovarian granulose cells induced by copper. J Environ Sci Health A Tox Hazard Subst Environ Eng 49: 625-633, 2014.

SIROTKIN AV: New endocrine and intracellular regulators of ovarian functions. Endocrine Abstracts 32: P583, 2013.

SIROTKIN AV, GROSSMANN R: Role of tyrosine kinase- and MAP kinase-dependent intracellular mechanisms in control of ovarian functions in the domestic fowl (Gallus domesticus) and in mediating effects of IGF-II. J Reprod Dev 49: 99-106, 2003.

SIROTKIN AV, GROSSMANN R: The role of protein kinase A and cyclin-dependent (CDC2) kinase in the control of basal and IGF-II-induced proliferation and secretory activity of chicken ovarian cells. Anim Reprod Sci 92: 169-181, 2006.

SIROTKIN AV, MAKAREVICH AV, PIVKO J, KOTWICA J, GENIESER H, BULLA J: Effect of cGMP analogues and protein kinase G blocker on secretory activity, apoptosis and the cAMP/protein kinase A system in porcine ovarian granulosa cells in vitro. J Steroid Biochem Mol Biol 74: 1-9, 2000.

SIROTKIN AV, SANISLO P, SCHAEFFER HJ, FLORKOVICOVA I, KOTWICA J, BULLA J, HETENYI L: Thrombopoietin regulates proliferation, apoptosis, secretory activity and intracellular messengers in porcine ovarian follicular cells: involvement of protein kinase A. J Endocrinol 183: 595-604, 2004.

SIROTKIN AV, MLYNCEK M, MAKAREVICH AV, FLORKOVICOVA I, HETENYI L: Leptin affects proliferation-, apoptosis- and protein kinase A-related peptides in human ovarian granulosa cells. Physiol Res 57: 437-442, 2008.

SUN XX, BOSTROM SL, GRIFFITH LC: Alternative splicing of the eag potassium channel gene in drosophila generates a novel signal transduction scaffolding protein. Mol Cell Neurosci 40: 338-343, 2009.

TOMANEK M, CHRONOWSKA E: Immunohistochemical localization of proliferating cell nuclear antigen (PCNA) in the pig ovary. Folia Histochema Cytobiol 44: 269-274, 2006.

WYLLIE A, DONAHUE MS, FISCHER B, HILL D, KEESEY J, MANZOW S: In: Apoptosis and Cell Proliferation. Edn 2, Boehringer, Mannheim, 1998, pp 1-5, 64-66.

XIA Z, DICKENS M, RAINGEAUD J, DAVIS RJ, GREENBERG ME: Opposing effects of ERK and JNK-p38 MAP kinases on apoptosis. Science 270: 1326-1331, 1995.

ZU L, HE J, JIANG H, XU C, PU S, XU G: Bacterial endotoxin stimulates adipose lipolysis via toll-like receptor 4 and extracellular signal-regulated kinase pathway. J Biol Chem 284: 5915-5926, 2009. 